\title{
Wpływ palenia tytoniu na wybrane właściwości fizykochemiczne śliny — przegląd piśmiennictwa
}

\author{
Influence of tobacco smoking on physicochemical \\ properties of saliva - literature review \\ Katedra i Zakład Periodontologii i Chorób Błony Śluzowej Jamy Ustnej, Gdański Uniwersytet Medyczny
}

DOI: http://dx.doi.org/10.20883/df.2018.28

\begin{abstract}
STRESZCZENIE
Dym tytoniowy zawiera wiele substancji chemicznych o potwierdzonym badaniami działaniu cytotoksycznym i karcynogennym. W obrębie jamy ustnej jako pierwsza kontakt z dymem tytoniowym ma ślina, w której składzie fizykochemicznym można obserwować zmiany wywołane paleniem. Dym tytoniowy wpływa na obniżenie zdolności immunologicznych śliny, między innymi poprzez zmniejszenie stężenia IgA, jak również na potencjał antyoksydacyjny śliny, co może skutkować zwiększeniem zawartości wolnych rodników. Dym tytoniowy, powodując zmiany w zawartości substancji nieorganicznych, przyczynia się do zmiany składu płytki nazębnej, przyspieszając jej mineralizację. U palaczy tytoniu stwierdzono także osłabienie działania niektórych białek enzymatycznych występujących w ślinie.
\end{abstract}

Słowa kluczowe: palenie tytoniu, ślina, właściwości śliny.

\section{ABSTRACT}

Tobacco smoke contains numerous chemicals with confirmed cytotoxic and carcinogenic effects. Saliva is the first biological liquid to be in contact with tobacco smoke in the oral cavity, which leads to changes in its composition. Tobacco smoke reduces saliva's immune capacity affecting the amount of IgA and the antioxidant potential of saliva, which can result in an increased number of free radicals. The components of tobacco smoke contribute to changes in the composition of dental plaque and accelerate its mineralization by changing the amount of inorganic substances. Cigarettes smoking has also been proven to diminish the activity of some enzyme proteins present existing in saliva.

Keywords: tobacco smoke, saliva, saliva properties.

\section{Wstęp}

Dym tytoniowy zawiera ponad 4000 związków chemicznych, z których około 400 jest potwierdzonymi karcynogenami. Zaliczają się do nich między innymi aminy aromatyczne, wielopierścieniowe węglowodory aromatyczne, nitrozaminy oraz aldehydy [1, 2]. Aldehydem, który w dymie tytoniowym występuje w najwyższym stężeniu, jest acetaldehyd - substancja działająca silnie mutagennie i karcynogennie. Cytotoksycznie działającymi aldehydami są również akroleina i aldehyd krotonowy występujące $w$ znacznie niższym stężeniu niż acetaldehyd [3]. W dymie tytoniowym znajdują się również wolne rodniki, wykazujące potencjał karcynogenny $[2,4]$. Pierwszym płynem biologicznym, który ma kontakt $z$ dymem tytoniowym, jest
Ślina $[5,6]$ i z tego względu stanowi również pierwszą linię obrony przed występującymi w nim szkodliwymi substancjami [5].

\section{Właściwości fizykochemiczne śliny}

Ślina jest wydzieliną stale produkowaną przez duże i małe gruczoły ślinowe, której podstawową funkcją jest zapewnianie homeostazy w środowisku jamy ustnej [7]. Głównie składa się z wody (około 99\%), ale zawiera również substancje organiczne oraz nieorganiczne, warunkujące jej właściwości fizykochemiczne. Do organicznych składników śliny zaliczamy białka, niebiałkowe substancje azotowe, węglowodany, lipidy i hormony. Substancje nieorganiczne występują w postaci jonowej i nale- 
żą do nich sód, potas, wapń, magnez, chlor, fluor, jod oraz wodorowęglany i fosforany $[8,9]$. Poszczególne związki występujące w ślinie pełnią ściśle określoną rolę $\mathrm{w}$ prawidłowym funkcjonowaniu ekosystemu jamy ustnej. Glikoproteiny śliny nawilżają błonę śluzową oraz zapewniają ochronę przed uszkodzeniami mechanicznymi. Obecność buforujących jonów wodorowęglanowych i fosforanowych umożliwia neutralizowanie kwasów pochodzących z pożywienia oraz będących produktem metabolizmu bakterii. Niektóre białka występujące w ślinie, do których zalicza się amylaza, wykazują właściwości enzymatyczne. W ślinie znajduje się również wiele elementów o działaniu przeciwbakteryjnym. Należy do niech między innymi lizozym, enzym powodujący rozkładanie ścian komórkowych bakterii, prowadząc do ich zniszczenia, występują również immunoglobuliny $A$, leukocyty oraz enzymy, takie jak sialoperoksydaza, laktoferryna i histamina [8-11]. Ślina zawiera także antyoksydanty, do których należy kwas moczowy, glutation, kalalaza, peroksydaza, peroksydaza glutationowa oraz dysmutaza ponadtlenkowa [1, 12, 13]. Ich zadaniem jest neutralizacja wolnych rodników tlenowych [14]. Wiele czynników pochodzenia endogennego i egzogennego może wpływać na zmianę składu śliny, co upośledza jej funkcje. Jednym z nich jest dym tytoniowy [15]. Związki chemiczne występujące $w$ dymie tytoniowym mogą rozpuszczać się $w$ ślinie, prowadząc do zaburzeń w jej składzie [16]. U palaczy tytoniu zaobserwowano wiele zmian właściwości fizykochemicznych śliny, między innymi obniżenie poziomu lgA, histaminy, niektórych substancji nieorganicznych oraz zaburzenia $\mathrm{w}$ potencjale antyoksydacyjnym [15, 17-21].

\section{Wpływ palenia tytoniu na poziom IgA w ślinie}

U palaczy tytoniu zaobserwowano obniżenie poziomu immunoglobuliny A w ślinie w porównaniu do osób niepalących [17]. Potwierdziły to również badania przeprowadzone przez Barton JR i wsp., które wykazały obniżenie poziomu IgA i podwyższenie IgM u palaczy. Zaobserwowane zjawiska były zależne od częstotliwości ekspozycji na dym tytoniowy oraz odwracalne po zaprzestaniu palenia. Wyniki badań dowodzą, że dym tytoniowy wpływa na osłabienie działania układu immunologicznego [22]. Immunoglobulina A jako jedyne przeciwciało jest aktywnie wydzielana do śliny, a jej stężenie w ślinie u osób bez stwierdzonych zmian patologicznych w przyzębiu jest stosunkowo niskie. Wzrasta natomiast w przypadku występowania za- palenia przyzębia, stanowiąc mechanizm obronny przed bodźcami antygenowymi pochodzącymi z biofilmu bakteryjnego płytki nazębnej. IgA może występować również jako swoista immunoglobulina przeciwko A. Actinomycetemcomitans — została stwierdzona u pacjentów z zapaleniem przyzębia opornym na leczenie [9]. Obniżenie poziomu IgA może prowadzić do osłabienia swoistej odpowiedzi immunologicznej i wcześniejszego rozwoju zapalenia przyzębia o bardziej nasilonym przebiegu [18].

\section{Wpływ palenia tytoniu na zawartość histaminy w ślinie}

Dym tytoniowy modyfikuje również działanie układu immunologicznego poprzez wpływ na zawartość histaminy $w$ ślinie, co zostało udowodnione przez Bertl i wsp. [18]. Histamina jest aminą wazoaktywną uczestniczącą $w$ reakcjach alergicznych oraz immunologicznych, zwiększając produkcję IL-8, $\mathrm{PGE}_{2}$, cyklooksygenazy oraz receptorów Toll-like 2 i $4[18,23]$. Powoduje również zwiększenie odpowiedzi zapalnej $w$ fibroblastach dziąseł, a jej poziom zwiększa się w przypadku występowania zapalenia przyzębia [24]. Badania śliny pobranej od pacjentów z zapaleniem przyzębia wykazały, że u osób palących występuje znacząco statystycznie wyższy poziom histaminy niż u osób niepalących. Prawidłowa zawartość histaminy jest potrzebna do powstania specyficznej reakcji immunologicznej podczas infekcji, a jej zaburzenia predysponują do rozwoju stanu zapalnego, w tym zapalenia przyzębia [18]. Określanie poziomu histaminy w ślinie może być wykorzystane jako biomarker zapalenia przyzębia, ponieważ jej podwyższony poziom jest charakterystyczny dla stanu zapalnego i koreluje z zaawansowaniem choroby.

\section{Wpływ dymu tytoniowego na skład jonowy śliny}

W wyniku działania dymu tytoniowego stwierdzono zmiany w zawartości sodu, wapnia, magnezu oraz fosforanów w ślinie pomiędzy osobami palącymi i niepalącymi tytoń. W badaniach przeprowadzonych przez Kotle i wsp. [19], Nakonieczna i wsp. [25], oraz Zuabi i wsp. [26] stwierdzono obniżenie poziomu wapnia, sodu i magnezu. $Z$ kolei Shashikanth i wsp. stwierdzili nieistotny statystycznie wzrost poziomu wapnia [27]. Znacząco wyższe stężenie wapnia $w$ ślinie stymulowanej wśród osób palących wykazały badania prowadzone przez Sevon i wsp. [28] oraz McGregor i wsp. [29]. Zaobserwowane zjawisko może być związane ze zmniejszeniem gęstości tkanki kostnej będącym jednym ze znanych działań niepożądanych pale- 
nia tytoniu [28]. Konsekwencją zwiększenia zawartości jonów wapnia w ślinie może być przyspieszenie mineralizacji płytki nazębnej $[27,30]$. Z drugiej strony zwiększenie stężenia jonów wapnia może przyczynić się do wzrostu odporności zębów na próchnicę [31]. Wzrost zawartości jonów wapnia prawdopodobnie wiąże się ze wzrostem stężenia fosforanów, ale nie zostało to jednoznacznie potwierdzone [27]. Kotle i wsp. [19] oraz Zuabi i wsp. [26] zaobserwowali nieistotny statystycznie wzrost zawartości fosforanów w ślinie osób palących tytoń, natomiast Erdemir i wsp. [32] nie wykazali żadnych różnic w zawartości fosforanów w ślinie między palaczami tytoniu a osobami niepalącymi. Rozbieżności w zaobserwowanych zjawiskach mogą wynikać z różnic w wykorzystanych technikach prowadzenia badań. Otrzymane wyniki, pomimo występujących sprzeczności, wskazują jednak, że palenie tytoniu wpływa na skład jonowy śliny, ale potrzebne są bardziej szczegółowe badania, które pozwolą dokładnie ocenić występujące zmiany [27].

\section{Wpływ palenia tytoniu na antyoksydanty}

Palenie tytoniu zaburza również działanie antyoksydantów obecnych w ślinie, co zostało potwierdzone w badaniach przeprowadzonych przez Nagler i wsp. [13], Zappacosta i wsp. [1], Baharvand i wsp. [33], Greabu i wsp. [34], Bakhtiari [20] oraz Klein i wsp. [30]. Udowodniono, że całkowity potencjał antyoksydacyjny u palaczy tytoniu był istotnie statystycznie niższy niż u osób niepalących. Najprawdopodobniej było to spowodowane obecnością u palaczy dużej liczby wolnych rodników i w konsekwencji powstania stresu oksydacyjnego [20, 21]. Podobne wyniki badań otrzymali Abdolsamadi i wsp. stwierdzając, że określanie poziomu antyoksydantów może być wykorzystane do oceny stresu oksydacyjnego spowodowanego paleniem tytoniu [35]. Z kolei Baharvand i wsp. udowodnili, że aktywność dysmutazy ponadtlenkowej była wyższa u palaczy tytoniu niż u osób niepalących [33]. Klein i wsp. potwierdzili, że u palaczy tytoniu aktywność peroksydazy w ślinie była znacząco niższa, w związku z cyjanowodorem występującym w dymie tytoniowym [36]. Według badań przeprowadzonych przez Zappacosta i wsp. ważną rolę w neutralizowaniu szkodliwego wpływu dymu tytoniowego spełnia glutation, który oprócz pełnienia funkcji antyoksydacyjnej neutralizuje również działanie aldehydów. Prawdopodobnie jest to spowodowane reakcją zachodzącą pomiędzy grupami aldehydowymi i grupami -SH glutationu [37]. Również w badaniach Greabu i wsp. wykazano znaczący wpływ wolnych rodników zawartych w dymie tytoniowym na działanie antyoksydantów, zwłaszcza kwasu moczowego stanowiącego ponad połowę zdolności antyoksydacyjnych śliny. Zaobserwowano obniżenie i utratę jego aktywności enzymatycznej, co prowadziło do powstawania odpowiedzi zapalnej oraz rozpoczęcia procesu karcynogenezy [38]. Różnice w otrzymanych wynikach mogły być spowodowane różną intensywnością palenia tytoniu wśród badanych osób, sposobem odżywiania oraz metodą prowadzenia badań. Nie ulega jednak wątpliwości, że palenie tytoniu modyfikuje potencjał antyoksydacyjny śliny [20,39, 40]. Wolne rodniki zawarte w dymie tytoniowym są kojarzone z zapoczątkowaniem oraz przyspieszaniem procesu nowotworzenia w różnych tkankach, między innymi w obrębie jamy ustnej [41, 42].

\section{Wpływ palenia tytoniu na białka enzymatyczne}

Palenie tytoniu obniża również zdolności enzymatyczne białek występujących w ślinie, między innymi dehydrogenazy mleczanowej i amylazy ślinowej [5, 37] oraz kwaśnej fosfatazy [5]. Weiner i wsp. wykazali, że w wyniku ekspozycji śliny na dym tytoniowy amylaza ślinowa znacząco utraciła swoją aktywność [15]. Za szkodliwy wpływ dymu tytoniowego na zdolności enzymatyczne białek przede wszystkim odpowiedzialne są aldehydy, będące głównym źródłem podwójnych wiązań wchodzących w reakcje chemiczne z grupami -SH białek [3, 5]. Zaobserwowane zjawiska według Zappacosta i wsp. [37] występowały już po wypaleniu jednego papierosa. W kontekście prowadzonych badań wykazano również ochronną rolę glutationu, który zmniejsza wywołane przez aldehydy zmiany w białkach enzymatycznych $[5,15$, 37]. $Z$ kolei w badaniach Nagler i wsp. nie zaobserwowano wpływu palenia tytoniu na aktywność fosfatazy alkalicznej oraz aminotransferazy aspartanowej [5].

\section{Podsumowanie}

Wiele przeprowadzonych badań śliny wykazało zmiany $w$ jej składzie jonowym, supresję odpowiedzi immunologicznej oraz zaburzenie działania antyoksydantów w wyniku działania dymu tytoniowego. Bardzo istotne $w$ aspekcie zdrowia jamy ustnej wydaje się kontynuowanie badań w kierunku oceny wpływu dymu tytoniowego na inne elementy odpowiedzialne za mechanizmy obronne organizmu, istotne zarówno $\mathrm{w}$ patogenezie chorób jamy ustnej, jak i schorzeń ogólnoustrojowych. Biorąc pod uwagę łatwą dostępność śliny jako ma- 
teriału diagnostycznego, badania śliny stają się obecnie szczególnie istotne w odniesieniu do progresji niektórych chorób rozwijających się w obrębie jamy ustnej, między innymi choroby przyzębia i chorób błony śluzowej jamy ustnej.

\section{Oświadczenia}

Oświadczenie dotyczące konfliktu interesów

Autorzy deklarują brak konfliktu interesów w autorstwie oraz publikacji pracy.

\section{Źródła finansowania}

Autorzy deklarują brak źródeł finansowania.

\section{Piśmiennictwo}

[1] Zappacosta B, Persichilli, De Sole P, Mordente A, Giardia B. Effect of smoking one cigarette on antioxidant metabolites in the saliva of healthy smoker. Arch Oral Boil. 1999;44:485-8.

[2] Hecht SS. Advances in tobacco carcinogenesis. Handbook of Experimental Pharmacology. Grover P. Springer -Verlag. 1989.

[3] O'Neill CA, Halliwell B, Van der Vliet A i wsp. Aldehyde induce protein modification in human plasma: protection by glutathione and dihydrolipolic acid. J Lab Clin Med. 1994;124:359-69.

[4] Alberg AJ. The influence of cigarette smoking on circulatory concentrations od antioxidant micronutrients. Toxicology. 2002;180:121-37.

[5] Nagler R, Lischinsky S, Diamond E i wsp. Effect of cigarette smoke on salivary proteins and enzyme activities. Arch Biochem Biophys. $2000 \mathrm{Ju}$ 15;379(2):229-36.

[6] Kanehira T, Shibata K, Kashiwasaki H, Lnoue N, Morita $\mathrm{M}$. Comparison of antioxidant enzyme in saliva of elderly smok- ers \& non-smokers. Gerodontology. 2006;23:38-42.

[7] Pink R, Simek J, Vondrakova J. Saliva as a diagnostic medium. Biomed Pap Med Fac Univ. Palacky Olomouc Czech Republic. 2009;153:103-110.

[8] Piątowska D i wsp. Kariologia współczesna. Med Tour Press International. 2009; s. 95-106.

[9] Eley BM, Soory M, Manson JD. Periodontologia. Elsevier Urban \& Partner 2011; s. 20, 43-48.

[10] Dyba J, Lenkowski M, Surdacka A. Evaluating the diagnostic potential of saliva in respect of periodontal disease as well as changes occurring within the endothelium. Dental Forum. 2017;1(XLV).

[11] Wolf HF, Rateitschak EM, Rateitschak KH. Periodontologia. Czelej 2006; s. 51-54.

[12] Battino M, Ferrero MS i wsp. The antioxidant capacity of saliva. J Clin Periodontal. 2002;29:189-94.

[13] Nagler RM, Klein I, Zarzhersky N, Drigues N, Reznick AZ. Characterization of the differentiated antioxidant profile of human saliva. Free Radic Biol Med. 2002;32:268-77.

[14] Mandel ID. The role of saliva in maintaining oral homeostasis. J Am Dent Assoc. 1989;119:298-304.
[15] Weiner D, Levy Y, Khankin EV, Reznick AZ. Inhibition of salivary amylase activity by cigarette smoke aldehydes. Journal of Physiology and Pharmacology. 2008;59(Suppl. 6):727-737.

[16] Salaspuro V, Salaspuro M. Synergistic effect of alkohol drinking and smoking on in vitro acetaldehyde concentration in saliva. Int J Cancer. 2004;111: 480-83.

[17] Bennet KR, Reade PC. Salivary immunoglobulin A levels in normal subjects, tobacco smokers and patents with minor apthous ulceration. Oral Sure Oral Med Pathol. 1982;53:461-65.

[18] Bertl K, Haririan H, Laky M i wsp. Smoking influences salivary histamine levels in periodontal disease. Oral Diseases. 2012;18:410-416.

[19] Kolte AP, Kolte RA, Laddha RK, Effect of smoking on salivary composition and periodontal status. J Indian Soc Periodontol. 2012 Jul-Sep;16(3):350-353.

[20] Bakhtiari S, Azimi S, Mehdipour M i wsp. J Dent Res Dent Clin Dent Prospect. 2015;9(4):281-284.

[21] Mojtaba E, Davood K, Hussein D. Lower total antioxidant capacity in smokers compare to non- smokers. Biological Forum - an International Journal. 2014;6:305-309.

[22] Barton JR, Riad MA, Gaze MN, et al. Mucosal immunodeficiency in smokers, and in patients with epithelial head and neck tumours. Gut. 1990;31: 378-382.

[23] Theoharides TC, Cochrane DE. Critical role of mast cells in inflammatory diseases and the effect of acute stress. J Neuroimmunol. 2004;146:1-12.

[24] Minami T, Kuroishi T, Ozawa A i wsp. Histamine amplifies immune response of gingival fibroblasts. J Den Res. 2007;86:1083-88.

[25] Nakonieczna-Rudnicka M, Bachanek T, Rogowska W. Concentration of calcium ions in the saliva and the value of the $\mathrm{pH}$ of the saliva in female and male smokers. Przegl Lek. 2009;66:652-654.

[26] Zuabi O, Machtei EE i wsp. The effect of smoking and periodontal treatment on salivary composition in patients with established periodontitis. J Periodontal. 1999;70:1240-46.

[27] Shashikanth H, Raghavendra U, Naveena N, Rajesh KS. Assessment of Salivary Composition in Smokers and Non Smokers With Chronic Periodontitis. Journal of Dental and Medical Sciences. 2016 June;15(6): 84-88.

[28] Sewon L,Laine $M$, Karjalanien S, Dorpguinskania A,Lentonen-Veromaa M. Salivary calcium concentration reflects skeletal osteoporotic changes in heavy smokers. Arch Oral Biol. 2004;49:335-358.

[29] Mac Gregor DM, Edgar WM. Calcium and phosphate concentrations and precipitate formation in whole saliva in smokers and non smokers. J Periodontol Res. 1986;21:429-33.

[30] Sewon L, Makela M. A study of possible correlation between high salivary calcium level and dental conditions in young adults. Arch Oral Biol. 1990;35: 211-12.

[31] Kasagani SK, Rao A, Rajan S, Fatima G, Tapashetti R. Estimation of Salivary and Serum Calcium Levels in Smokers and Nonsmokers with Chronic Periodonti- 
tis. Journal of Health Science \& Research, July-December. 2016;7(2):35-37.

[32] Erdermir EO, Erdemir A. The detection of salivary minerals in smokers and Non smokers with chronic periodontitis by the inductively coupled plasma atomic emission spectrophotometry technique. J Periodontol. 2006;77:990-995.

[33] Baharvand M, Maghami AG, Azimi S, Bastani H, Ahmadieh A, Taghibakhsh M. Comparison of superoxide dismutase ac- tivity in saliva of smokers and nonsmokers. South Med J. 2010;103:425-7.

[34] Greabu M, Totan A, Battino M, Mohora M, Didilescu A, Totan C, et al. Cigarette smoke effect on total salivary anti- oxidant capacity, salivary glutathione peroxidase and gamma-glutamyltransferase activity. Biofactors. 2008;33:129-36.

[35] Abdolsamadi HR, Goodarzi MT, Mortazavi H, Robati M, Ahmadi-Motemaye F. Comparison of salivary antioxidants in healthy smoking and non-smoking men. Chang Gung Med J. 2011;34:607-11.

[36] Klein I, Nagler RM, Toffler R, Der Vliet A, Reznick AZ. Effect of cigarette smoke on oral peroxides activity in human saliva: role of hydrogen cyanide. Free Radical Biology \& Medicine. 2003;35;11:1448-52.

[37] Zappacosta B, Persichilli S, Mordente A, Minucci A i wsp. Inhibition of salivary enzymes by cigarette smoke ans the protective role of glutathione. Human \& Experimental Toxicology. 2002;1:7-11.

[38] Greabu M, Battino M, Totan A, Motora M i wsp. Effect of gas phase of cigarette smoke on salivary antioxidants. What can be the role of vitamin C and pyridoxine? Pharmacological Reports. 2007;59:613-618.
[39] Konopka T, Król K, Kopeć W. Wpływ nikotynizmu i zapaleń przyzębia na wybrane parametry stresu oksydacyjnego. Wiad Lek. 2006;7-8(59):463-470.

[40] Konopka T, Kopeć W. Wpływ nikotynizmu na parametry stresu oksydacyjnego u pacjentów z zapaleniami przyzębia. Czas Stomatol. 2006;59(Supl. 1):24.

[41] Hamo Mahmood I, Abdullah Ks, Othman SH.The total anti-oxidant status in cigarette smoking individuals. MJBU. 2007;25:45-50.

[42] Lee BM, Lee SK, Kim HS. Inhibition of oxidative, DNA damage, 8-OHdG and carbonyl contents in smokers treated with antioxidants (vitamin $\mathrm{E}$, vitamin $C$, betacarotene 8 red gingseng). Cancer Lett. 1998;132:219-27.

Zaakceptowano do edycji: 2018-10-16 Zaakceptowano do publikacji: 2018-12-05

Adres do korespondencji:

Aida Kusiak

Katedra i Zakład Periodontologii i Chorób Błony

Śluzowej Jamy Ustnej

Gdański Uniwersytet Medyczny

u. Elizy Orzeszkowej 18, 80-204 Gdańsk

tel./fax: +48583491667

e-mail: akusiak@gumed.edu.pl 